littoral area into three natural algal belts correlated with the run of the tide. This tidal flow theory also fits closely to the observed distribution of various animal species inhabiting the sandy and muddy areas of the tidal zone. Mr. A. C. Stephen, following up his previous reports on molluscan ecology, has found that in 1933 the density of population of Tellina tenuis was far in excess of any previously met with, on an average 8214 per square metre. This was largely composed of a very abundant spat. The closely related $T$. fabula was also very successful in its spatting, but the conditions were evidently not so favourable for the common cockle, Cardium edule, very little spat of this species occurring. Dr. Orr, Dr. Marshall and Dr. Nicholls, in continuing their co-operative work on the plankton with special reference to Calanus, have shown that the success or failure of a brood depends on the presence or absence of diatoms during the early stages of development. A study of the chemical composition of Calanus showed that the fat content followed the changes in weight, and that the protein content also followed in general the changes in weight. Spent females were rarely found, which indicates that they die soon after spawning. An unusual occurrence was noted in the behaviour of Stage V Calanus on one occasion, when they swarmed actually on the surface of the water for two or three days, remaining in the upper few metres nearly all the time and only showing a tendency to seek deeper water during the darkest part of the night, which is a complete reversal of the normal migration. This subject is undergoing further investigation.

\section{Public Health in England and Wales, 1934-35}

THE sixteenth annual report of the Ministry of Health, 1934-35, has recently been issued, and deals under six sections with the whole subject of the public health and its administration in England and Wales (Cmd. 4978. H.M. Stationery Office, 1935. 5s. 6d. net.). Sir Kingsley Wood, the Minister of Health, in his introduction, contrasts mortality rates for the years 1910 and 1933. Thus, the death rates per 1,000 living for these two years were, respectively, $13 \cdot 2$ and $9 \cdot 3$; the infant mortality rates were 105 and 64 , the death rates per million from pulmonary tuberculosis were 988 and 639 , and for typhoid fover, 53 and 5. Maternal mortality, however, in spite of the development of maternity services in recent years, has not yet begun to fall. Statistics of vaccination show a slight but steady decline, from $42 \cdot 6$ per cent of total births in 1928 to $37 \cdot 0$ in 1933. Samples of food and drugs analysed during 1934 numbered 140,583 , a small increase over the previous year, of which $7,45 \mathrm{I}$ or $5 \cdot 3$ per cent were reported against. It is mentioned that in some districts there are signs of revival and expansion of canal traffic, and there is evidence that motor traction of canal boats is continuing to develop, for many motor-propelled boats are on order, such boats being notable for improvements in design as regards ventilation and sanitation compared with the old type of boat.

\section{Destructive Earthquakes in 1935}

IN a recent number of the Matériaux pour l'Étude des Calamités (No. 35, 82-86; 1935), M. Charles Bois continues his record of destructive earthquakes. During the first six months of this year, there were 16 such earthquakes, four of them resulting in considerable loss of life, namely, the Persian earthquake of April 11 (480 deaths), the Formosa earthquake of April 20 (3,065), the Caucasian earthquake of May 1 (600) and the Quetta earthquake of May 30 $(40,000)$. The latter number is probably too high, the latest estimate being about 30,000 . On the other hand, the number of deaths $(2,000)$ given by M. Bois for the Bihar earthquake of January 15, 1934 (Nature, 136, 472, September 21, 1935), is too low, the number given in the official report on the earthquake being more than 10,000 .

\section{Third World Power Conference}

THE third World Power Conference will be held in Washington, U.S.A. on September 7-12, 1936. This will be the third plenary meeting of the World Power Conference, the first plenary meeting having taken place at Wembley in 1924, and the second at Berlin in 1930. There have, in addition, been a number of sectional meetings. The Chemical Engineering Congress of the World Power Conference, to be held in London next June, ranks as one of these series of sectional meetings. The general subject to be discussed at the Third World Power Conference is "National Power Economy". Among the aspects to be treated are the following : physical and statistical bases; technical, economic and social trends; organisation of fuel industries and of gas and electric utilities; public regulations; national and regional planning; conservation of fuel and water resources; rationalisation of distribution; national power and fuel policies. The second Congress of the International Commission on Large Dams of the World Power Conference will be held in Washington at the same time. Further particulars regarding the plenary meeting of the World Power Conference and the second International Congress on Large Dams will be issued in due course. British participation will be organised by the British National Committee of the World Power Conference, 36 Kingsway, London, W.C.2.

\section{Work of the Medical Research Council}

Is a pamphlet by Miss Norah Dacre Fox, issued by the London and Provincial Anti-Vivisection Society, an attempt is made to criticise the work carried out under the Medical Research Council. Reference is made to the dominating influence of the late Sir Walter Fletcher, to vested interests, to a suppressed report, etc. It is stated : "The public is the Master, the Medical Research Council its servant. Is it not entitled to assert itself and to require from those it remunerates so lavishly, an account of this steward. ship ?" Needless to say, an account of this stewardship is available to all who desire it in the annual report and in the numerous research reports issued by the Council. 


\section{Announcements}

Prof. JoHn A. RYLE, regius professor of physic in the University of Cambridge, and Prof. Matthew J. Stewart, professor of pathology in the University of Leeds, have been appointed members of the Medical Research Council in succession to the Right Hon. Lord Dawson of Penn, and Prof. A. E. Boycott.

Aт the annual dinner of the Institute of Fuel, held on October 9, the Melchett Medal was presented to Mr. Harry R. Ricardo for his work on internal combustion engine operation and its relation to fuel.

Ar the annual general meeting of the Association of British Chemical Manufacturers, Dr. E. F. Armstrong was elected president in succession to Sir Christopher Clayton.

The new auxiliary laboratory of the British Electrical and Allied Industries Research Association will be opened by H.R.H. The Duke of Kent at Perivale, Middlesex, on October 22, at 3 p.m.

The eleventh annual Norman Lockyer Lecture of the British Science Guild will be given by Sir Josiah Stamp, who has chosen as his subject "The Calculus of Plenty". The lecture is to be delivered in the Goldsmiths' Hall (by permission of the Goldsmiths' Company) on Wednesday, November 13, at 4.30 p.m.

DR. E. L. HIRsT will deliver a lecture on "The Chemical Nature of Vitamins" before the University of Durham Philosophical Society on November 1 at 6.30. The meeting will be open to the public.

Sir Walter Langdon-Brown will deliver the fifth Victor Horsley Memorial Lecture in University College Hospital Medical School, Gower Street, W.C.1, on November 19 at 5 p.m. The subject of the lecture will be "The Integration of the Endocrine System". Admission to the lecture will be free.

It has been decided to hold the Huxley Lecture at the Imperial College of Science and Technology in alternate years only, and in the other years to hold lectures commemorating other distinguished men who have served on the staff of the College. The first of the new series of lectures will be held on May 4, 1936, at 5.30 p.m., and will be given by Prof. G. T. Morgan. The lecture will be called "The Hofmann Memorial Lecture".

THE second Hinchley Memorial Lecture of the Institution of Chemical Engineers will be delivered by Sir Harold Hartley on October 25, at 6.30 , in the Lecture Theatre of the Institution of Civil Engineers, Great George Street, S.W.1. The subject of the lecture will be "Our National Coal Resources". The lecture is open to non-members, for whom tickets can be obtained from the Assistant Secretary, Abbey House, Westminster, S.W.1.

THE first Italian congress on alimentation, organised by the National Medical Syndicate, the committee for the study of the problems of alimentation and the National Research Council, will be held in Rome on October 23-26. At the inaugural meeting, Prof. Filippo Bottazzi will speak on the organisation of scientific research in the service of the national food supply, and Prof. Eugenio Morelli will discuss the work of the doctor in alimentary propaganda.

Prof. Bernardo A. Houssay, of the Institute of Physiology, Buenos Aires, has been appointed a member of the Permanent International Committee of the Physiological Congresses. The names of the other members of the Committee were given in NATURE of October 12 in the article on the recent Congress held in the U.S.S.R. (see p. 573). Prof. Houssay's election is a welcome acknowledgment of the value of the work of the growing schools of physiology in South America.

Messrs. Allen and Unwin, Ltd., announce the early publication of "Coral Gardens and Their Magic" by Prof. Bronislaw Malinowski ; also "How Animals Develop" by C. H. Waddington, which affords a short account of the science of embryology.

Messrs. W. Watson and Sons, Ltd., 313 High Holborn, W.C.1, have recently circulated a new issue of part 6 of their microscope catalogue, dealing with microscopes and accessories for polarising purposes, which will be sent gratis to those interested. Two new models have been introduced, the 'Service', 'School of Mines', and 'Advanced' petrological models have been re-designed, and the last two can now be supplied with horse-shoe, instead of tripod, foot if preferred. A demonstration set has also been designed for school purposes in order to demonstrate the phenomena of polarised light, and other new patterns of apparatus are figured and described.

Applications are invited for the following appointments, on or before the dates mentioned:

A lecturer in mining in the University of LeedsThe Registrar (Oct. 22).

An examiner in the Aeronautical Inspection Directorate-The Secretary (S.2.d.), Air Ministry, Kingsway, W.C.2 (Oct. 26).

An assistant engineer in the Chief Engineer's Department of the London County Council-The Clerk to the Council, County Hall, S.E.I (Oct. 28).

A lecturer in electrical engineering and a lecturer in mathematics and electrical engineering in the South-East London Technical Institute-The Education Officer, County Hall, S.E.l (Oct. 28).

A junior scientific officer and an assistant (III) at the Building Research Station, Garston-The Establishment Officer, Department of Scientific and Industrial Research, 16 Old Queen Street, S.W.1 (Oct. 30).

A lecturer in mathematies in the Edinburgh Training Centre-Prof. Godfrey H. Thomson, Director of Studies, Moray House, Edinburgh, 8 (Oct. 30).

A lecturer in mathematics in the Saltley Church of England Training College for Schoolmasters, Birmingham-The Principal (Nov. 1). 